\title{
New Generation of Passenger Vehicles: FCV or HEV?
}

\author{
H. Moghbelli ${ }^{1}$, A. Halvaei Niasar ${ }^{2}$, R. Langari ${ }^{3}$ \\ ${ }^{1}$ Department of Electrical \& Computer Engineering, Isfahan University of Technology, Isfahan, Iran, $\underline{\text { hmoghbelli@uh.edu }}$ \\ ${ }^{2}$ Department of Electrical Engineering, Iran University of Science \& Technology, Tehran, Iran, halvaei@ieee.org \\ ${ }^{3}$ Mechanical Engineering Department, Texas A\&M University, College Station, TX 77843, rlangari@tamu.edu
}

\begin{abstract}
This paper compares the performance and parameter characteristics of Fuel Cell Vehicles (FCV) and Hybrid Electric Vehicles (HEV) with a view towards an objective assessment of the relative performance of these vehicles. Firstly, the main characteristics of hybrid electric vehicles (HEVs) as low emission vehicles (LEVs), including presumed high efficiency is considered. Then, comparisons for well-to-wheels emissions for various vehicles are presented. Well-to-wheels efficiencies, emissions, and fuel economy are also compared for FCVs and HEVs. In addition, other issues like battery types for HEVs and HFCVs are explored in this paper. The potential control strategies for FCVs and HEVs will be discussed and compared. In both FCVs and HEVs, best control strategies need to rely on predicting the driver command, which presents a particularly challenging opportunity for further development. Finally, this paper gives the comparison of total costs for FCVs and HEVs.
\end{abstract}

\section{Key words}

HEV, FCV, Emission, Fuel Economy, Efficiency, Battery

\section{Introduction}

Fuel cell vehicles (FCV) are widely believed to be the only viable alternative to internal combustion engine vehicles (ICEV) in ground transportation, other than hybrid electric vehicles (HEV). Replacement of internal combustion engine (ICE) with fuel cell system could save $60 \%$ of the primary energy consumption, the $\mathrm{CO}_{2}$ emission can be reduced by about $55 \%$, and release of toxic substances could be largely reduced, as presented in the next section. Some of the disadvantages for FCVs are cost, new and untested technology in vehicles, and fueling infrastructure problems. For automotive applications, fuel cell systems are not yet competitive with ICE for performance, packaging, cost, fuel storage, and high-volume manufacturability [1].

HEVs are considered to be a better alternative to ICEVs, because of some of the problems mentioned above for FCVs. There are two basic types of HEVs, based on the source of power for the vehicle. They are series hybrids-in which electric motor drives the vehicle from the battery pack and the ICE powers a generator that charges the battery; and parallel hybrids - in which power is delivered through both the electric motor and the internal combustion engine. HEVs have several advantages, as they offer performance and fuel economy in the same package. Specifically in reference to series hybrid configuration, there are three primary advantages to hybridizing an internal combustion engine vehicle:

(1) Enabling the engine to operate at higher fraction of its peak load and therefore at higher efficiencies.

(2) De-coupling the engine from the instantaneous torque and speed requirements at the wheels.

(3) The ability to capture some of the energy normally lost in braking through regenerative braking. An electric motor connected to the drive wheels acts as a generator during braking, effectively converting mechanical energy to charge the batteries [2].

Both FCVs and HEVs require significant investment of effort and time from the auto manufacturers and researchers, for their successful commercialization. But currently there is ambiguity as to which vehicle in the future provides the best value for the invested efforts. In this paper, we seek to answer the question by comparing various issues for both the FCVs and HEVs. The different issues that will be considered for comparison are performance, well-to-wheel efficiencies, total-cycle emissions, alternative fuels, and hybridization of FCVs etc [3].

For both FCVs and HEVs, the consumer needs to be satisfied by its performance characteristics, such as the acceleration, braking, the feel of driving etc. Other parameters like efficiency, emissions, weight etc. of any vehicle also needs to be competitive with alternative technologies. The parameter comparisons between FCV and HEV are given in Table I. Based on the performance and parameter comparison, it can be concluded that FCVs can compete well with HEVs on both levels.

\section{Emissions}

One of the true advantages of FCVs is low vehicle emissions. In case of Direct Hydrogen Fuel Cell Vehicle (DHFCV), the vehicle emissions are just water and electricity. It is a true Zero emissions vehicle (ZEV). In case of Direct Methanol Fuel Cell Vehicle (DMFCV) and Indirect Methanol Fuel Cell Vehicle (IMFCV), the main emission is carbon dioxide or carbon monoxide, which is converted into carbon dioxide. HEVs also offer potential for low vehicle emissions compared to ICEVs. This can be achieved in HEVs by shutting down the IC engine during idling and also by using mostly battery power in areas such as cities, where there is more population density $[3,4]$. 
TABLE I. Parameter Comparison of HEV and FCV

\begin{tabular}{|c|c|c|c|c|c|c|c|c|}
\hline $\begin{array}{c}\text { Vehicle } \\
\text { Type }\end{array}$ & $\begin{array}{c}\text { Total } \\
\text { Efficiency }\end{array}$ & Emissions & Mass & $\begin{array}{l}\text { Energy } \\
\text { Density }\end{array}$ & Acceleration & Refueling & $\begin{array}{c}\text { Startup } \\
\text { Time }\end{array}$ & $\begin{array}{c}\text { Energy } \\
\text { Capture }\end{array}$ \\
\hline HEV & $\begin{array}{l}\text { Estimated } \\
\text { to have a } \\
\text { potential to } \\
\text { reach } 40 \% \\
\text { efficiency. }\end{array}$ & $\begin{array}{l}\text { Relatively } \\
\text { lower } \\
\text { emissions } \\
\text { compared to } \\
\text { ICEV; but } \mathrm{CO}_{2} \\
\text { emissions still } \\
\text { exist }\end{array}$ & $\begin{array}{l}\text { Additional mass } \\
\text { due to the weight } \\
\text { of the batteries } \\
\text { because of low } \\
\text { specific energy } \\
\text { of batteries }\end{array}$ & $\begin{array}{l}\text { Zinc and } \\
\text { Aluminum } \\
\text { Air Batteries } \\
\text { have the } \\
\text { highest } \\
\text { energy } \\
\text { density in } \\
\text { batteries: } \\
200 \mathrm{Wh} / \mathrm{kg} \text {. }\end{array}$ & $\begin{array}{l}\text { Can give } \\
\text { desired } \\
\text { acceleration } \\
\text { and maximum } \\
\text { speed range } \\
\text { due to power } \\
\text { from battery }\end{array}$ & $\begin{array}{l}\text { Vast } \\
\text { infrastructu } \\
\text { re exists for } \\
\text { gasoline, } \\
\text { diesel fuels }\end{array}$ & $\begin{array}{l}\text { No } \\
\text { significant } \\
\text { startup } \\
\text { time }\end{array}$ & $\begin{array}{l}\text { Can capture up } \\
\text { to } 20-25 \% \\
\text { energy } \\
\text { required to } \\
\text { drive a HEV } \\
\text { by } \\
\text { regenerative } \\
\text { braking. [5] }\end{array}$ \\
\hline FCV & $\begin{array}{l}\text { Total } \\
\text { efficiency } \\
\text { of an FCV } \\
\text { including a } \\
\text { reformer is } \\
\text { in the } \\
\text { range } 24- \\
32 \% \text {. For } \\
\text { DHFCV: } \\
60-65 \%\end{array}$ & $\begin{array}{l}\text { Zero emissions } \\
\text { in the case of } \\
\text { direct hydrogen } \\
\text { FCV; ultra-low } \\
\text { emissions in } \\
\text { case of direct } \\
\text { and indirect } \\
\text { methanol FCVs }\end{array}$ & $\begin{array}{l}\text { Vehicle mass } \\
\text { increased even } \\
\text { without IC } \\
\text { engine. Current } \\
\text { prototypes report } \\
\text { an average } \\
\text { increase in mass } \\
\text { of about } 500 \mathrm{~kg} . \text {, } \\
\text { compared to their } \\
\text { standard } \\
\text { counterparts. }\end{array}$ & $\begin{array}{l}\text { Energy } \\
\text { density of } \\
\text { methanol is } \\
\text { about } 6100 \\
\mathrm{Wh} / \mathrm{kg} \text {, and } \\
\text { for liquid } \mathrm{H}_{2} \text {, } \\
\text { it is } 39 \\
\mathrm{kWh} / \mathrm{kg}\end{array}$ & $\begin{array}{l}\text { Efficiency } \\
\text { drops at very } \\
\text { low or very } \\
\text { high power } \\
\text { demands }\end{array}$ & $\begin{array}{l}\text { Refueling } \\
\text { infrastructure } \\
\text { nonexistent, } \\
\text { which is a } \\
\text { major } \\
\text { hindrance }\end{array}$ & $\begin{array}{l}\text { Minimu } \\
\text { m startup } \\
\text { time of } \\
10 \text { sec. } \\
\text { But } \\
\text { research } \\
\text { underway } \\
\text { to reduce } \\
\text { it. }\end{array}$ & $\begin{array}{l}\text { Can have the } \\
\text { advantage of } \\
\text { regenerative } \\
\text { braking for } \\
\text { HFCVs }\end{array}$ \\
\hline
\end{tabular}

\section{A. Comparison of FCV Well-to-Wheel Emissions with ICEV}

FCVs and HEVs offer potential for low vehicle emissions but one should evaluate the well-to-wheel emissions of a vehicle to understand the environmental advantage that particular vehicle offers. Fig. 1 shows the comparison of well-to-wheel $\mathrm{CO}_{2}$ emissions for various vehicles. $\mathrm{CO}_{2}$ emissions are estimated from primary resource extraction through vehicle end use. As can be seen from Fig. 1, $\mathrm{CO}_{2}$ emissions are reduced by more than $50 \%$ for FCV and just below $50 \%$ for IMFCV, DHFCV and reformulated gasoline (RFG) HEV, compared to Gasoline ICEV [6].

Fig. 2 shows the comparison of other emissions like Nitrous oxides $\left(\mathrm{NO}_{\mathrm{x}}\right)$, Hydrocarbons $(\mathrm{HC}), \mathrm{SO}_{2}$ and Carbon monoxide (CO) for various vehicles. As can be seen from Fig. 2, there is huge reduction in $\mathrm{CO}$ emissions for both types of FCVs, compared to the ICEVs. It is easy to see the advantages of FCVs compared with ICEVs, in terms of emissions from both Fig. 1 and Fig. 2. [6].

\section{B. Comparison of Well-to-Wheels Emission of FCV and HEV}

All the technology investment for HEVs and FCVs could become redundant if the emissions technology of gasoline vehicles is going to improve drastically over the next few years to give Super Ultra Low Emissions Vehicle (SULEV) emissions. A study by Wang shows a sample of results for the Greenhouse gas $\left(\mathrm{CO}_{2}, \mathrm{~N}_{2} \mathrm{O}\right.$, etc.) emissions obtained with assumptions for U.S. passenger car technologies expected to be available in the year 2010. Fig. 3 gives the emission results obtained in a graphical form [7]. As can be observed from the Fig. 3, there is a major reduction projected in the greenhouse gas emissions for the FCVs compared to HEVs in the near future. It is easy to see the advantages of the FCVs compared to other types of vehicles including HEVs, in terms of total fuel-cycle emissions.

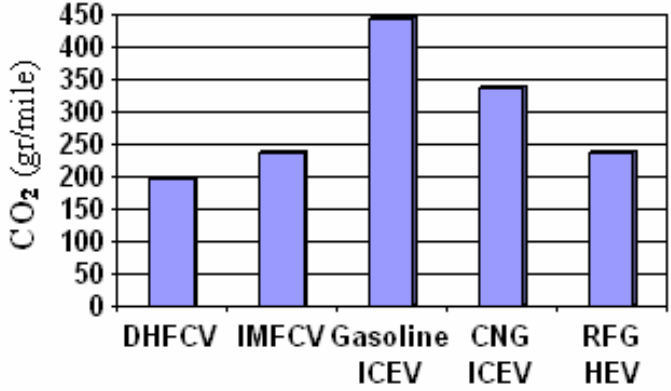

Fig. 1. Comparison of well-to-wheel $\mathrm{CO}_{2}$ emissions for various vehicles

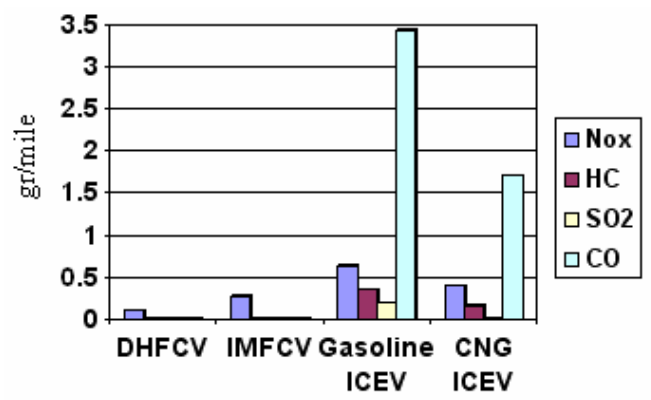

Fig. 2. Comparison of well-to-wheel emissions for various vehicles

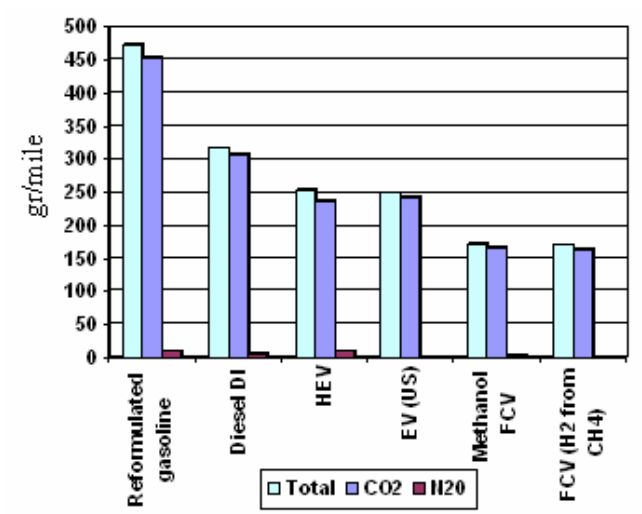

Fig. 3. Comparison of well-to-wheel emissions for various passenger cars of 2010 


\section{Well-to-Wheel Efficiencies and Fuel Economy}

Efficiency is one of the important characteristics of any system. Fuel cells are very efficient systems. If a fuel cell is powered with pure hydrogen, it has the potential to be 65-70 percent efficient. Fuel economy is also a very important consideration for FCVs. Well-to-wheels efficiency is a combination (product) of well-to-vehicle and vehicle-to-wheels efficiencies. Well-to-vehicle efficiency is a product of all the efficiencies right from fuel extraction to transportation to supply to storing in a fuel tank of a vehicle. Similarly, Vehicle-to-wheels efficiency is the calculated based on the final use of the fuel on a vehicle, where fuel is processed to provide power to a vehicle.

\section{A. Comparison of Well-to-Wheel Efficiency for HEVs and FCVs}

A comparison of true efficiency for FCVs and HEVs with ICEVs and Battery Electric Vehicles (BEVs) is given in this section. Table II gives the total well-to-wheels efficiencies for each of the vehicle. It is observed that DHFCV is the most efficient in the well-to-wheels comparison. The BEV and Gasoline FCV come next with similar overall efficiencies. The Natural Gas Vehicle and the Series Hybrid vehicle are next efficient vehicles. The ICEV is least efficient of the lot with about $13.7 \%$ efficiency [8]. Total well-to-wheels efficiency from raw resource extraction to final use is shown in Fig. 4 for the $600 \mathrm{~km}$ range vehicle. The efficiency is stated in miles per gallon of equivalent gasoline energy at the oil or gas well. The efficiencies are calculated by a team at Princeton University based on a simulation program [8]. It is noted that $\mathrm{BEV}$ is extremely inefficient for long distances, while is competitively efficient for the short range.

As expected the DHFCV is more efficient than any other vehicle. And also a Gasoline FCV is more efficient than an HEV. Parallel HEVs are likely to be both more efficient and less costly than series HEVs, according to a study by the Center for Transportation Research (CTR) [9]. So the difference between the "well to wheels" efficiencies of the HEVs and the FCVs is not going to be a decisive factor in favoring towards a particular vehicle. However, as mentioned earlier, there are several other parameters like total costs, emissions etc. to be considered before favoring a particular type of vehicle.

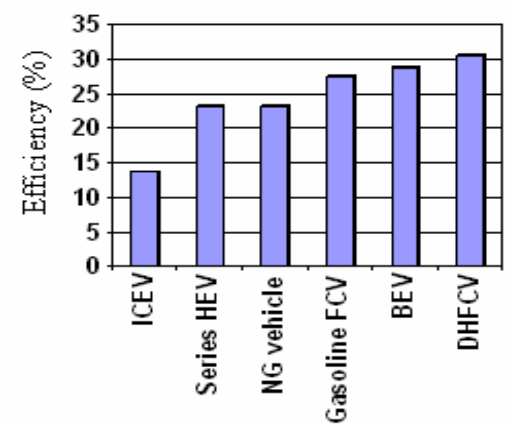

Fig. 4. Well-to-wheels efficiency comparison between various vehicles from simulation studies
TABLE II. Well-to-Wheel Efficiencies $(\mathrm{X} \times \mathrm{Y})$

\begin{tabular}{|c|c|c|c|c|c|c|}
\hline Efficiency & ICEV & $\begin{array}{c}\text { Series } \\
\text { HEV }\end{array}$ & $\begin{array}{c}\text { Natural } \\
\text { Gas } \\
\text { Vehicle }\end{array}$ & $\begin{array}{c}\text { FCV with } \\
\text { reformer }\end{array}$ & BEV & DHFCV \\
\hline $\mathrm{x}$ & 0.86 & 0.86 & 0.86 & 0.86 & 0.36 & 0.65 \\
$\mathrm{y}$ & 0.16 & 0.27 & 0.27 & 0.32 & 0.80 & 0.47 \\
\hline$(\mathrm{x} \times \mathrm{y})$ & 0.137 & 0.232 & 0.232 & 0.275 & 0.28 & 0.305 \\
\hline
\end{tabular}

\section{B. Fuel Economy Comparison Between FCV and HEV}

Directed Technologies Inc. presented a comparison of fuel economy between the ICEVs (gasoline, natural gas), hybrid vehicles (natural gas, diesel) and fuel cell vehicles (hydrogen, methane and gasoline)[11]. Fig. 5 shows the fuel economy comparison between various vehicles for the EPA 55/45 cycle. All fuel economies are based on EPA 55/45 combined drive cycle, but at 1.25 times the speeds suggested in the drive cycle specifications. In case of HEVs, the comparison is given between parallel HEV and two types of series HEVs - the load-following series and the thermostat series HEVs. The Load Following Series HEV uses the electric motor as the primary propulsion system until the battery SOC is depleted down to a range between an upper and lower switching threshold. Within this range the ICE supplies the power train requirements, with the batteries acting as a load leveling device. In case of the thermostat series HEV, an electric motor supplies all the mechanical power to the wheels. The ICE is turned on at a fixed power level when the battery state of charge (SOC) reaches a pre-set minimum and turned off when the SOC exceeds a maximum, independent of the electric motor power requirements.

It is noted that the Diesel Parallel HEV gives a mileage of 58 miles per gallon (mpg), the IMFCV gives $45 \mathrm{mpg}$, whereas the DHFCV gives $65 \mathrm{mpg}$. It is observed that the diesel parallel HEV gives a fuel economy almost equivalent to the DHFCV [12].

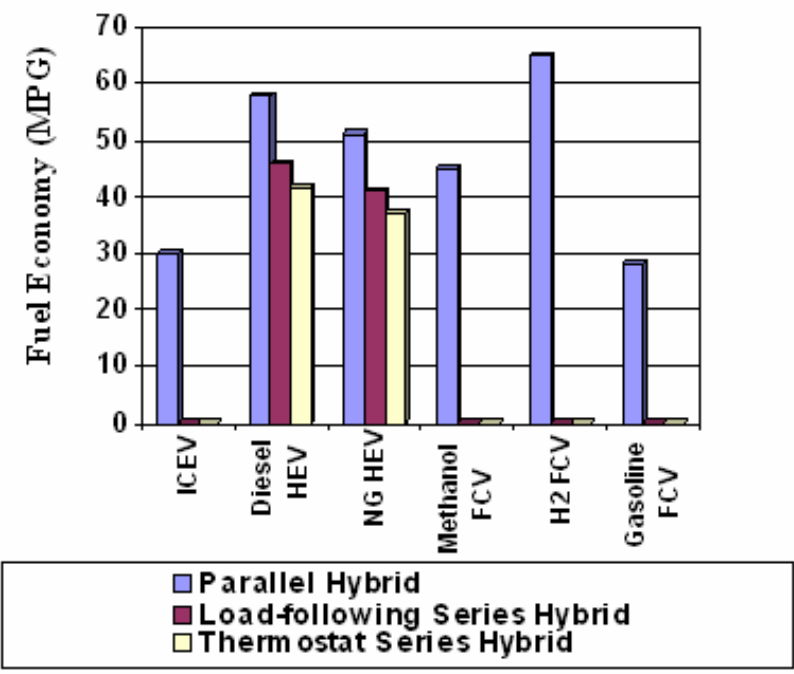

Fig. 5. Fuel economy comparison for various vehicles for 1.25 times faster EPA 55/45 cycle [11] 
TABLE III. Key Parameters of Various Batteries

\begin{tabular}{|c|c|c|c|c|c|c|c|c|c|}
\hline Battery Type & $\begin{array}{c}\text { Energy } \\
\text { Density } \\
{[\mathrm{Wh} / \mathrm{kg}]}\end{array}$ & $\begin{array}{c}\text { Power } \\
\text { Density } \\
{[\mathrm{W} / \mathrm{kg}]}\end{array}$ & $\begin{array}{l}\text { Cycle } \\
\text { Life }\end{array}$ & $\begin{array}{c}\text { Operating Temp. } \\
{[\mathrm{C}]}\end{array}$ & $\begin{array}{c}\text { Storage } \\
\text { Temp. [C] }\end{array}$ & Maturity & $\begin{array}{c}\text { Current Cost } \\
{[\$ / \mathrm{kWh}]}\end{array}$ & $\begin{array}{c}\text { Future Cost } \\
\{\$ / \mathrm{kWh}]\end{array}$ & Principal Manuf. \\
\hline Lead-Acid & 25 to 35 & 75 to 130 & $\begin{array}{c}200 \text { to } \\
400\end{array}$ & -18 to +70 & Ambient & Production & 100 to 125 & 75 & $\begin{array}{l}\text { Trojan, Hawker, } \\
\text { Exide, Interstate }\end{array}$ \\
\hline $\begin{array}{c}\text { Advanced Lead } \\
\text { Acid }\end{array}$ & 35 to 42 & 240 to 412 & $\begin{array}{c}500 \text { to } \\
800\end{array}$ & N/A & N/A & Production & N/A & N/A & $\begin{array}{l}\text { Delphi, Horizon, } \\
\text { Electrosource }\end{array}$ \\
\hline \begin{tabular}{|c|} 
Nickel-Metal \\
Hydride
\end{tabular} & 50 to 80 & 150 to 250 & $\begin{array}{c}600 \text { to } \\
1500 \\
\end{array}$ & N/A & N/A & Prototype & 525 to 540 & 115 to 300 & $\begin{array}{c}\text { Panasonic, } \\
\text { Ovonic, SAFT }\end{array}$ \\
\hline $\begin{array}{c}\text { Nickel- } \\
\text { Cadmium }\end{array}$ & 35 to 57 & 50 to 200 & $\begin{array}{c}1000 \text { to } \\
2000\end{array}$ & -40 to +60 & -60 to +60 & Mature & 300 to 600 & 110 & SAFT \\
\hline Lithium-Ion & 100 to 150 & 300 & $\begin{array}{c}400 \text { to } \\
1200\end{array}$ & N/A & N/A & Laboratory & N/A & N/A & SONY, SAFT \\
\hline \begin{tabular}{|l|} 
Zinc-Bromide \\
\end{tabular} & 56 to 70 & 100 & 500 & N/A & N/A & & 300 & N/A & N/A \\
\hline $\begin{array}{l}\text { Lithium } \\
\text { Polymer }\end{array}$ & 100 to 155 & 100 to 315 & $\begin{array}{c}400 \text { to } \\
600\end{array}$ & 60 to 100 & N/A & Laboratory & N/A & 100 & N/A \\
\hline $\mathrm{NaNiCl}$ & 90 & 100 & & $\begin{array}{c}270 \text { to } 350 \text { (300 } \\
\text { optimal) }\end{array}$ & N/A & Prototype & N/A & N/A & AEG Anglo \\
\hline Zinc-Air & 110 to 200 & 100 & $\begin{array}{c}240 \text { to } \\
450\end{array}$ & N/A & N/A & Prototype & 300 & 100 & Liquid Fuel Ltd \\
\hline $\begin{array}{l}\text { Vanadium } \\
\text { Redox }\end{array}$ & 50 & 110 & 400 & N/A & N/A & N/A & 300 & N/A & N/A \\
\hline
\end{tabular}

\section{Efficiency Comparison Between FCV and HEV}

Based on Fig. 4 and Fig. 5, it can be concluded that:

(1) Various vehicles arranged in ascending order in terms of well to wheel efficiencies: ICEV, Series HEV, Parallel HEV, IMFCV and DHFCV.

(2) The difference between the "well to wheels" efficiencies of the HEV and the FCV is not going to be a decisive factor in favoring towards a particular vehicle, as the number is not that large. Also there are several other parameters like total costs, emissions etc. to be considered before favoring a particular type of vehicle.

(3) It is observed that the diesel parallel HEV gives a fuel economy almost equivalent to the DHFCV in the EPA 55/45 cycle. The IMFCV gives a lesser mileage in comparison with these two types.

\section{Batteries for Hybrid Electric Vehicles}

There are several batteries available for use in hybrid vehicles (HEVs and HFCVs), each having its own advantages and limitations. A detailed list can be found in [13]. It is believed that the batteries that serve the purpose for HEVs also function well for HFCVs. Table III lists several types of batteries along with their common characteristics. The types are listed in descending order of popularity for use in hybrid vehicles, with the most popular choices at the top of the table.

Many HEV designs typically cycle the batteries between $20 \%$ and $80 \%$ states of charge. This type of "short cycling" leads to premature loss of capacity. This is due to the fact that it is critically important that batteries be fully charged, at least periodically. In most HEV designs, since the batteries are never fully charged, the inevitable result is early failure. This means that if the battery is not adequately charged, cycle life expectancy will be compromised. One method to avoid the situation is to use an off-board charger that would be able to periodically recharge the batteries fully [14].

\section{Control Strategies}

FCVs require a good control strategy for proper fuel management and to meet some of the transient demands. HEVs require proper control strategy to maintain SOC of the batteries and to optimize one or more of the parameters like the fuel economy, emissions and performance. This section describes and compares different control strategies for FCVs and HEVs [15].

\section{A. FCV Control Strategies}

Proper fuel management is very important in an FCV, as the characteristics of the fuel used are quite complex. Meeting the transient demands and optimizing the power generation of the FCV are also some important considerations. Table IV lists six of the FCV control strategies aiming to meet some of the above desired characteristics, giving a brief description of each strategy with its advantages and disadvantages. Among the six strategies, the power-averaging scheme, the utilization scheme and the backpressure strategy are the three best strategies, because of their simplicity, feasibility and not compromising on both performance and fuel economy.

\section{B. HEV Control Strategies}

For an HEV, the flexibility in the design comes from the ability of the control strategy to manage how much power is flowing to or from each component. There are many desirable objectives for HEVs such as maximize fuel economy, minimize emissions, minimize propulsion system cost to keep overall vehicle cost affordable to the consumer market and do all of the above while maintaining or improving upon acceptable performance. Some of the control strategies accomplishing the above objectives are mentioned in table V. Among the above five different control strategies, the Electrically Peaking Hybrid strategy and the Parallel Hybrid strategy are the two best HEV control strategies. 


\section{Flexibility of Application of FCV and HEV Control Strategies}

From the tables IV and V, it can be observed that each control strategy has its own advantages and disadvantages. Therefore, an appropriate control strategy needs to be chosen based on the advantages, simplicity, feasibility of implementation and applicability to a particular vehicle. Among the FCV control strategies,
Power-averaging Scheme can be applied to any hybrid vehicle and Equivalent Consumption Minimization strategy can be applied to any hybrid FCV. Moreover, among the HEV control strategies, Electrically Peaking Hybrid concept and Mild HEV control strategies can be applied to any type of hybrid vehicles. All the other control strategies are specific to that particular application.

TABLE IV. Advantages and Disadvantages of Various FCV Control Strategies

\begin{tabular}{|c|c|c|c|c|}
\hline No. & Control Strategy & Description & Advantages & Disadvantages \\
\hline 1. & $\begin{array}{l}\text { Power-averaging } \\
\text { Scheme Control } \\
\text { Strategy [16] }\end{array}$ & $\begin{array}{l}\text { - For HFCV, the battery state-of- } \\
\text { charge is allowed to float } \\
\text { between } 60 \% \text { and } 40 \% \text {, } \\
\text { eliminating efficiency-drop }\end{array}$ & $\begin{array}{l}\text { - Stack not operated in the region } \\
\text { where its efficiency drops off } \\
\text { significantly other than when it is } \\
\text { idling } \\
\text { - Limits excursions into the very low } \\
\text { and very high power regions }\end{array}$ & $\begin{array}{l}\text { Specific to the drive train } \\
\text { considered. The optimum } \\
\text { range for the battery SOC } \\
\text { before recharging, varies } \\
\text { with the power capacities of } \\
\text { the fuel cell and the battery }\end{array}$ \\
\hline 2. & $\begin{array}{l}\text { Utilization } \\
\text { Scheme [17] }\end{array}$ & $\begin{array}{l}\text { - Fuel processor operating } \\
\text { pressure is varied slightly about } \\
\text { the nominal pressure }\end{array}$ & $\begin{array}{l}\text { - Uses the hydrogen rich reformate in } \\
\text { the fuel processor volume } \\
\text { - The stack operated at an optimum } \\
\text { supply level }\end{array}$ & $\begin{array}{l}\text { Extra hardware required in } \\
\text { the form of a back-pressure } \\
\text { valve to vary the fuel } \\
\text { processor operating pressure }\end{array}$ \\
\hline 3. & $\begin{array}{l}\text { Backpressure } \\
\text { Strategy [18] }\end{array}$ & $\begin{array}{l}\text { - Makes use of backpressure } \\
\text { control on the fuel processor to } \\
\text { account for variations in } \\
\text { hydrogen requirement }\end{array}$ & $\begin{array}{l}\text { - Clear and well-defined control } \\
\text { strategy }\end{array}$ & $\begin{array}{l}\text { - Separate control system and } \\
\text { hardware required to } \\
\text { implement this strategy }\end{array}$ \\
\hline 4. & $\begin{array}{l}\text { Maximum } \\
\text { Conversion } \\
\text { Efficiency Curve } \\
\text { strategy [19] }\end{array}$ & $\begin{array}{l}\text { - Maximizes the conversion } \\
\text { efficiency of a DMFCV over a } \\
\text { dynamic range of power }\end{array}$ & $\begin{array}{l}\text { - Optimizes the power output for a } \\
\text { given fuel flow rate or power level } \\
\text { - Significantly increases the fuel } \\
\text { utilization at low current (power) } \\
\text { levels, thus minimizing loss of } \\
\text { efficiency }\end{array}$ & $\begin{array}{l}\text { - Separate control system and } \\
\text { hardware required to } \\
\text { implement the variable- } \\
\text { concentration variable-flow } \\
\text { methanol feed stream to } \\
\text { DMFC stack }\end{array}$ \\
\hline 5. & $\begin{array}{l}\text { Current Control } \\
\text { and Throttle } \\
\text { Control Fuel Cell } \\
\text { System strategies } \\
{[20]}\end{array}$ & $\begin{array}{l}\text { - Improves the acceleration } \\
\text { performance of an FCV with } \\
\text { reformer }\end{array}$ & $\begin{array}{l}\text { - No major technical or hardware } \\
\text { limitations } \\
\text { - No significant sacrifice in fuel } \\
\text { economy } \\
\text { - No extra hardware required } \\
\end{array}$ & $\begin{array}{l}\text { - If fuel economy and vehicle } \\
\text { dynamics are both important } \\
\text { attributes, neither of these } \\
\text { simple strategies are realistic }\end{array}$ \\
\hline 6. & $\begin{array}{l}\text { Equivalent } \\
\text { Consumption } \\
\text { Minimization } \\
\text { strategy [21] }\end{array}$ & $\begin{array}{l}\text { - Employs a local minimization } \\
\text { criterion to minimize the overall } \\
\text { hydrogen consumption, for a } \\
\text { hybrid FCV }\end{array}$ & $\begin{array}{l}\text { - Optimal power for fuel cell } \\
\text { operation determined based on the } \\
\text { minimal hydrogen consumption for } \\
\text { fuel cell and battery powers, for a } \\
\text { specific demand } \\
\text { - The ECMS (Equivalent Consumption } \\
\text { Minimization Strategy) approach can also } \\
\text { be applied to other hybrid } \\
\text { configurations like fuel cell/ultra } \\
\text { capacitor }\end{array}$ & $\begin{array}{l}\text { - Sacrifices performance for } \\
\text { fuel economy. The elaborate } \\
\text { calculations involved make } \\
\text { the system slow } \\
\text { - The method is configuration- } \\
\text { specific. } \\
\text { - Operational data needs to be } \\
\text { modified for different vehicle } \\
\text { configurations }\end{array}$ \\
\hline
\end{tabular}

TABLE V. Advantages and Disadvantages of Various HEV Control Strategies

\begin{tabular}{|c|l|l|l|l|}
\hline No. & Control Strategy & \multicolumn{1}{c|}{ Description } & \multicolumn{1}{c|}{ Advantages } \\
\hline $\mathbf{1 .}$ & $\begin{array}{l}\text { Electrically } \\
\text { Peaking Hybrid } \\
\text { concept [22] }\end{array}$ & $\begin{array}{l}\text { - Uses the electric motor and fuel energy } \\
\text { source provider, usually the ICE, in a } \\
\text { parallel architecture }\end{array}$ & $\begin{array}{l}\text { - ICE used in high-speed region, } \\
\text { optimizing fuel economy } \\
\text { Performance and drive-comfort } \\
\text { comparable to conventional } \\
\text { vehicles }\end{array}$ \\
\hline 2. & $\begin{array}{l}\text { Parallel Hybrid } \\
\text { Control Strategy } \\
\text { [23] }\end{array}$ & $\begin{array}{l}\text { - The IC engine does not idle } \\
\text { - The motor performs regenerative } \\
\text { braking regardless of the batteries' SOC } \\
\text { - The IC engine provides the power } \\
\text { necessary to meet the trace } \\
\text { significant, requiring } \\
\text { more batteries }\end{array}$ & $\begin{array}{l}\text { Reduced emissions due to } \\
\text { elimination of ICE idling } \\
\text { Good fuel economy due to the } \\
\text { efficient operation of ICE }\end{array}$ \\
\hline
\end{tabular}




\begin{tabular}{|c|c|c|c|c|}
\hline 3. & $\begin{array}{l}\text { Series Hybrid } \\
\text { Design and } \\
\text { Control Strategy } \\
{[23]}\end{array}$ & $\begin{array}{l}\text { - ICE made unresponsive during hard } \\
\text { accelerations } \\
\text { - ICE handles loads within preset limits } \\
\text { and charges battery if SOC is below } \\
70 \% \\
\text { - ICE turned off at } 85 \% \text { SOC if not } \\
\text { necessary to supplement }\end{array}$ & $\begin{array}{l}\text { - Battery is made to handle high } \\
\text { power cycles without } \\
\text { degradation } \\
\text { - ICE is made to meet high } \\
\text { energy demands, hence no } \\
\text { idling }\end{array}$ & $\begin{array}{l}\text { - Series HEVs are } \\
\text { inherently less } \\
\text { efficient and more } \\
\text { costly than Parallel } \\
\text { HEVs }\end{array}$ \\
\hline 4. & $\begin{array}{l}\text { Power-follower } \\
\text { Series Hybrid } \\
\text { Control Strategy }\end{array}$ & $\begin{array}{l}\text { - The ICE power varies directly with the } \\
\text { tractive motor power, but is higher by a } \\
\text { SOC dependent factor to allow for } \\
\text { losses in the generator and battery. }\end{array}$ & $\begin{array}{l}\text { - Leads to better fuel economy } \\
\text { - ICE immediately follows } \\
\text { tractive power requirements, as } \\
\text { occurs in the parallel hybrid } \\
\text { and ICEVs, thus giving better } \\
\text { performance }\end{array}$ & $\begin{array}{l}\text { - No emissions benefit } \\
\text { over ICEVs, and are } \\
\text { chosen only for its } \\
\text { fuel economy } \\
\text { characteristics. }\end{array}$ \\
\hline 5. & $\begin{array}{l}\text { Mild HEV } \\
\text { Control Strategy }\end{array}$ & $\begin{array}{l}\text { - Uses a small electric motor with } \\
\text { floating stator, called Transmotor and } \\
\text { small battery pack }\end{array}$ & $\begin{array}{l}\text { - Recovers high braking } \\
\text { energy and reduces energy } \\
\text { losses, while meeting the } \\
\text { power demand }\end{array}$ & $\begin{array}{l}\text { - Complicated strategy and } \\
\text { hardware in the form of } \\
\text { clutches }\end{array}$ \\
\hline
\end{tabular}

\section{Total Cost}

It is important to consider FCVs and HEVs along with their financial implications, because if they are financially burdensome, consumers are not likely to favor them. This section discusses the incremental total cost of the components of FCV and HEV, as compared with ICEV. The costs presented here are only the estimated mass production costs [15].

\section{A. Incremental Costs of FCV and HEV Compared to ICEV}

The incremental mass production costs of each alternative vehicle are estimated compared to a conventional gasoline ICEV. The mass production cost estimates are made using the minimum costs for materials, production and assembly. The estimates for these vehicles are made with a detailed bottom-up design and costing procedure based on Ford costing methodology. The resulting mass production cost estimates for the gasoline ICEV drive train are compared with DHFCV and natural gas parallel HEV (NGHEV) drive trains and presented in table 3.

Fig. 6 presents the graphical comparison of the total costs of the vehicles mentioned above. It is observed that the HEVs are reasonably placed in total costs with respect to ICEVs, given the benefits they provide. However, DHFCV presents nearly a $100 \%$ increase in the total cost compared to which is probably due to the reason that the technology for FCVs is still at a nascent stage. Fig. 7 gives the incremental total cost comparison of other vehicles with respect to ICEV. Thus, it can be concluded that fuel cell vehicles can be competitive in terms of mass production costs with hybrid electric vehicles. Comparing the two most practical models, the Methanol FCV costs about $100 \%$ more than the diesel parallel HEV, in terms of incremental costs. This implies that more research needs to be done to bring the FCV costs down.

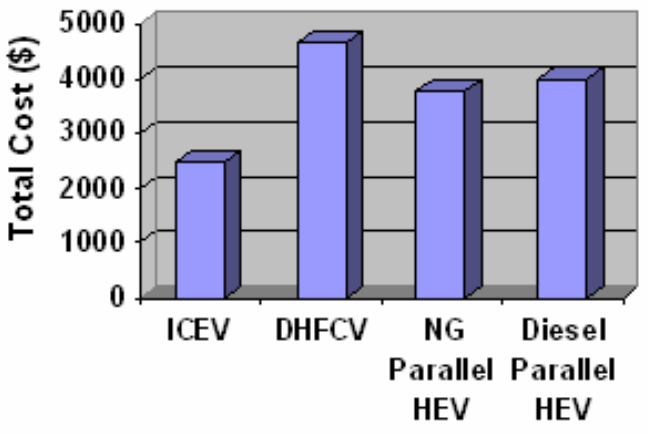

Fig. 6. Total cost comparison of various vehicles

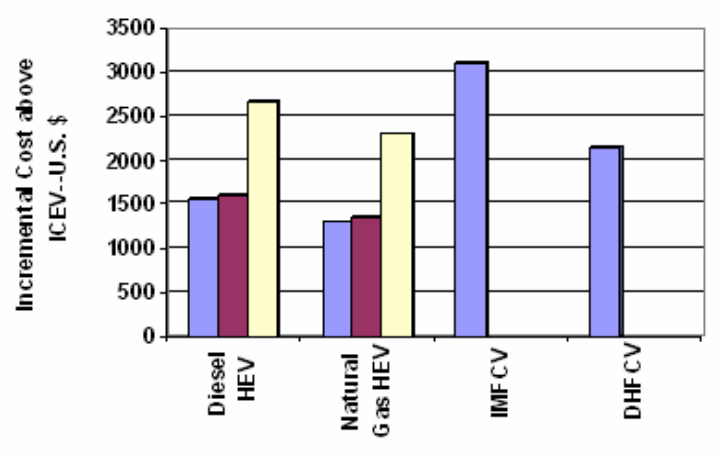

a Parallel Hybrid aLoad-following Series Hybrid aThermostat Series Hybrid

Fig. 7. Additional Mass Production Cost of Alternative Vehicles

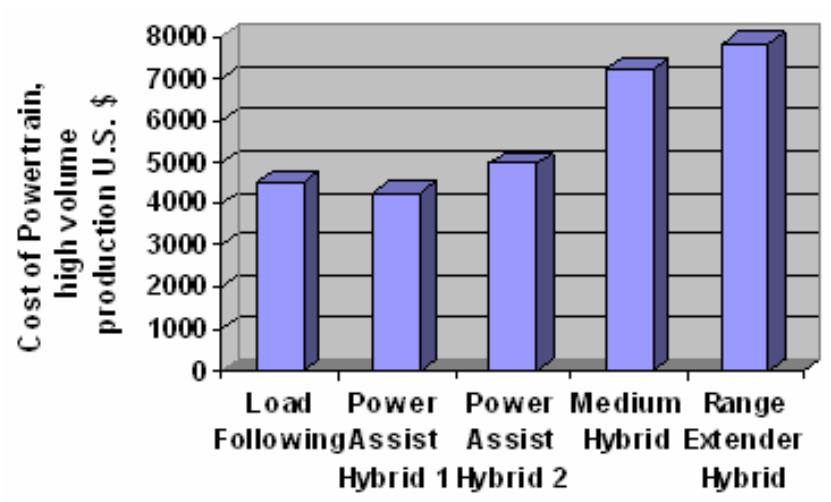

Fig. 8. Cost Comparison among the various fuel cell hybrid configurations 


\section{B. Cost Comparison among Hybrid Fuel Cell Vehicles (HFCVS)}

This section provides the comparison of the drive train costs of different HFCVs for high volume production. For conventional FCV, the drive train is made up of the fuel cell system, the electric motor drive and the electric motor controller. For hybrid FCV, a battery pack and a DC/DC converter are required along with the above components. The definition of the vehicle configurations considered for system simulation is given in the table VI. The cost comparison results for high volume production of different FCVs are given in Fig. 8. Compared to conventional FCV, the power train cost of:

- Power Assist Hybrid 1 is less by $5.6 \%$

- Power Assist Hybrid 2 is more by $10 \%$

- Medium Hybrid is more by $60 \%$

- Range Extender Hybrid is more by $73 \%$

It is noted that 'power assist hybrid 2' provides more power for just a fractional increment of cost over 'Load following' and 'power assist hybrid 1' FCVs. So if high performance is required of a vehicle, power assist hybrid 2 can be chosen as the drive train. As with the other configurations, the cost combined with other factors like performance, efficiency etc. should be considered while opting for hybridization of an FCV.

TABLE VI. Definition of Vehicle Configurations

\begin{tabular}{|c|c|c|c|c|}
\hline FCV Name & $\begin{array}{c}\text { Mass } \\
(\mathrm{kg})\end{array}$ & $\begin{array}{c}\text { Fuel cell } \\
\text { system } \\
\text { power }(\mathrm{kW})\end{array}$ & $\begin{array}{c}\text { Battery } \\
\text { power } \\
(\mathrm{kW})\end{array}$ & $\begin{array}{c}\text { Battery } \\
\text { Energy } \\
(\mathrm{kWh})\end{array}$ \\
\hline Load following & 1500 & 74 & 0 & 0 \\
\hline $\begin{array}{c}\text { Power Assist } \\
\text { Hybrid 1 }\end{array}$ & 1477 & 40 & 70 & 0.8 \\
\hline $\begin{array}{c}\text { Power Assist } \\
\text { Hybrid 2 }\end{array}$ & 1576 & 40 & 85 & 3.3 \\
\hline Medium Hybrid & 1662 & 43 & 45 & 13.9 \\
\hline $\begin{array}{c}\text { Range Extender } \\
\text { Hybrid }\end{array}$ & 1672 & 20 & 70 & 20.3 \\
\hline
\end{tabular}

\section{Conclusions}

Fuel cell vehicles (FCV) offer major reduction in "vehicle" emissions and also well-to-wheel emissions, compared to other types of vehicles. Even IMFCV, using a reformer, provides a reduction in greenhouse gas emissions of about $31.5 \%$ compared to gasoline HEV. When considering well-to-wheels efficiencies of various vehicles, it is observed that the difference between HEVs and FCVs is not large and is probably not going to be a decisive factor in choosing between FCV and HEV. It is also important to note that the fuel economy of diesel $\mathrm{HEV}$ is roughly competitive to DHFCV, whereas IMFCV has a lower mpg compared to these two types. As for performance, HEVs provide good performance without much efficiency penalty, as is the case with FCVs. However, for improved performance, FCVs have the option to be hybridized. For FCVs, hybridization will benefit those with significant transient limitations, as in
IMFCVs. However, much research needs to be done in this area to explore it comprehensively.

With regard to control strategies, $\mathrm{HEV}$ control strategies can also be applied to HFCVs, whereas the control strategies for FCVs are FCV-specific and cannot be used for HEVs. While considering the estimation of mass production costs, it is noted that DHFCV and IMFCV cost about $30 \%$ and $100 \%$ more than diesel HEV. This implies that for FCVs to be competitive to HEVs in automobile market, major technological innovations are needed in this area to bring down the costs of materials, components and production. FCVs are a long way away from commercialization, whereas HEVs are ready to be commercialized. For FCVs, major technological developments in fuel cell stack and auxiliaries are needed along with infrastructure development. For HEVs, development of batteries with higher specific energy and specific power and a significant reduction in electronic component costs are needed. Although other minor hurdles exist for HEVs, they can be overcome through the best efforts of automakers and researchers.

\section{References}

[1] M.Sadler et.al., "Warm-Up Strategies For a Methanol Reformer Fuel Cell Vehicle”, SAE Paper 2000-01-0371.

[2] David J.Friedman, University of California, "Maximizing Direct-Hydrogen PEM Fuel Cell Vehicle Efficiency - Is Hybridization Necessary?”, SAE Paper 1999-01-0530

[3] H. Moghbelli, K. Ganapavarapu, R. Langari, and M. Ehsani, "A comparative review of fuel cell vehicles (FCVs) and hybrid electric vehicles (HEVs) - Part I," in Proc. SAE Future Transportation Technology Conf., Costa Mesa, CA, June 2003.

[4] T. H. ORTMEYER, P. PILLAY, "Trends in transportation sector technology energy use and greenhouse gas emissions", PROCEEDINGS OF THE IEEE, VOL. 89, NO. 12, DECEMBER 2001, pp. 18371847.

[5] http://www.mtiresearch.com/technologies/ fuelcell/whatis.html

[6] http://www.solardome.com/solardome51.html

[7] Wang, M.Q., Argonne National Laboratory, Argonne, Ill., "GREET 1.5 - Transportation Fuel-Cycle Model: Volume 1, Methodology, Use, and Results, ANL/ESD-39, Vol.1”, Aug., 1999.

[8] Matthew Brekken et.al., "An Analysis of the True Efficiency of Alternative Vehicle Powerplants and Alternative Fuels”, SAE Paper 981399.

[9] http://transtech.anl.gov/v1n4/hev-report.html

[10] http://www.hydrogen.org/Knowledge/w-i-energieweng2.html

[11] C.E.Thomas et.al., "Societal Impacts of Fuel Options for Fuel Cell Vehicles”, SAE Paper 982496.

[12] A. Emadi, S. S. Williamson, "Fuel cell vehicles: opportunities and challenges", IEEE Power Engineering Society General Meeting, 2004.

[13] C.C.Chan, "The State of the Art of Electric and Hybrid Vehicles”, Invited Paper, IEEE Proceedings, Vol. 90, No. 2, Feb.2002

[14] K. Jana, Electric Vehicle application hand book for Genesis sealed-lead batteries, Fourth edition, Hawker Energy Products.

[15] H. Moghbelli, K. Ganapavarapu, and R. Langari, “A comparative review of fuel cell vehicles (FCVs) and 
hybrid electric vehicles (HEVs) - Part II " in Proc. SAE Future Transportation Technology Conf., Costa Mesa, CA, June 2003.

[16] David J.Friedman, University of California, "Maximizing Direct-Hydrogen PEM Fuel Cell Vehicle Efficiency - Is Hybridization Necessary?”, SAE Paper 1999-01-0530.

[17] Sitaram Ramaswamy et.al., University of California, "Fuel Processor for an Indirect Methanol Fuel Cell Vehicle", SAE Paper 2000-01-3111.

[18] Anthony Eggert et.al., University of California, "Simulated Performance of an Indirect Methanol Fuel Cell System", SAE Paper 2001-01-0544.

[19] R.M.Moore, University of California, S.Gottefeld and P.Zelenay, Los Alamos National Laboratory, “A Fuel Control Strategy that Optimizes the Efficiency of a Direct-Methanol Fuel Cell in an Automotive Application”, SAE Paper 1999-01-2913.

[20] Karl-Heinz Hauer et.al., University of California, "Dynamic Response of an Indirect-Methanol Fuel Cell Vehicle”, SAE Paper 2000-01-0370.

[21] Gino Paganelli et.al., Ohio State Univ., "Optimizing Control Strategy for Hybrid Fuel Cell Vehicle”, SAE Paper 2002-01-0102.

[22] Z.Rahman, K.L.Butler and M.Ehsani, Texas A\&M University, “A Study of Design Issues on Electrically Peaking Hybrid Electric Vehicle for Diverse Urban Driving Patterns”, SAE Paper 1999-01-1151.

[23] http://transtech.anl.gov/v1n4/hev-report.html

[24] http://www.altfuels.com/PDFs/CAFCPStudy01.pdf

[25] John DeCicco, Environmental Defense, "Fuel Cell Vehicles: Technology, Market, and Policy Issues", SAE Paper: 2002-01-1973 